\title{
EFFECTS OF MELIA AZEDARACH METHANOL EXTRACT AND NUCLEOPOLYHEDROVIRUS (SLNPV) ON SPODOPTERA LITTORALIS (BOISD.)
}

\author{
AHMED,YASMEIN A. EL SAYED ${ }^{1}$, HEBA YOUSEF ${ }^{1^{*}}$ and SHIMAA M. DESOKY ${ }^{2}$ \\ 1 Plant Protection Research Institute, ARC, Dokki, Giza \\ 2 Botany Department, Faculty of Science, Suez canal University. \\ * Author for correspondence and reprint requests E-mail: \\ hebayousef2004@yahoo.com
}

(Manuscript received 17 February 2014)

\begin{abstract}
Insecticidal activity of Melia azedarach methanol extract and nucleopolyhedrovirus (SLNPV) against Spodoptera littoralis larvae was evaluated under laboratory conditions. NPVs showed high significant toxicity on the $2^{\text {nd }}$ and $4^{\text {th }}$ instars larvae; while, the Melia extract was a relatively high toxic against the $2^{\text {nd }}$ instar larvae and less effective against the $4^{\text {th }}$ instar. The extract recorded strong reduction in larval weight as compared to the control. Generally, Melia extract potentiates the effect of SLNPV by producing mortality within a short time and negatively influences the larval growth and development which could result lesser feeding damage to the host plant.
\end{abstract}

Key words: Melia azedarach, Nucleopolyhedrovirus, Insecticidal Activity, Spodoptera littoralis.

\section{INTRODUCTION}

The Egyptian cotton leafworm, Spodoptera littoralis, is recorded in Africa, southern Europe, and the Middle East, where it is a particularly destructive pest of cotton and a wide range of economically important vegetables and ornamentals (Ellis, 2004).

Nucleopolyhedroviruses (NPVs), members of the family Baculoviridae, have received considerable attention as potential microbial insecticides, and some of the NPVs have been successfully used for the control of insect pests in agriculture (Moscardi, 1999). NPVs are safe and show selective biological control agents because of the little negative impact on non-target organisms and the environment.

The slow speed of action against target insects represents a serious disadvantage of NPVs as efficient insecticides, allowing the pests to infest the crops for considerable periods of time. Hence, knowledge of the effectiveness when combined with other insecticide especially plant-based insecticide is very much needed.

One member of the Meliaceae, known as Chinaberry or Persian lilac tree (Melia. azedarach) is a deciduous tree that is native to North Western India and has long recognized for its insecticidal properties. The effectiveness of extracts from fruits and 
leaves of Melia azedarach $\mathrm{L}$. has been previously demonstrated against insects (Sharma et al., 2012; Abou-Fakhr Hammad et al., 2013; Farag et al., 2011).

The Purpose of the present work was to study the insecticidal activity of $M$. azedarach methanol extract and NPVs against $S$. littoralis. The effectiveness of NPVs by binary mixture with strong antifeeding Melia azedarach methanol extract has been evaluated.

\section{MATERIALS AND METHODS}

\section{Strain of cotton leafworm S. littoralis}

The S. littoralis strain was obtained from the Faculty of Agriculture, Cairo University, Egypt, and was reared in the laboratory at the Pest Physiology Department, Plant Protection Research Institute, Agricultural Research Center, Giza, Egypt, as described by El-Defrawi et al., (1964), under constant laboratory conditions at $(25 \pm 1){ }^{\circ} \mathrm{C},(70 \pm 5)$ $\%$ relative humidity and a photoperiod of $16: 8 \mathrm{~h}$ (L:D). Adults were fed with a $15 \%$ solution of honey. Filter paper was provided as an oviposition site, and it was renewed periodically.

\section{Method of insect diet preparation}

The following diet ingredients were added to $1 \mathrm{Kg}$ of kidney beans soaked overnight.

\begin{tabular}{|c|c|}
\hline Bean & $1000 \mathrm{~g}$ \\
\hline Yeast extract & $120 \mathrm{~g}$ \\
\hline Ascorbic acid & $10 \mathrm{~g}$ \\
\hline Sorbic acid & $5 \mathrm{~g}$ \\
\hline Methyl hydroxyl benzoate & $10 \mathrm{ml}$ \\
\hline Agar & $80 \mathrm{~g}$ \\
\hline Sterile water & $900 \mathrm{ml}$ \\
\hline
\end{tabular}

The diet ingredients, except the agar and ascorbic acid, were blended in half volume of water. The agar was dissolved separately in the remaining water at $100^{\circ} \mathrm{C}$. The agar solution was mixed with other ingredients and after cooling below $70^{\circ} \mathrm{C}$, the ascorbic acid was added. 


\section{Preparation of NPVs}

\section{Virus propagation}

The $3^{\text {rd }}$ instar larvae of $S$. littorals were inoculated with SINPV isolate provided Insect Pathogen Unit, Plant Protection Research Institute, Agriculture Research Center by surface contamination of the artificial diet. The inoculated larvae were observed daily to identify the NPV $s$ infected ones based on the sign and symptoms of disease.

\section{Virus occlusion bodies purification}

The method of OBs purification was done as (Sudhakar et al., 1997) with some modification. The number of OBs was counted by using Neubaur Hemocytometer to determine the concentration of $\mathrm{OBs} / \mathrm{ml}$. Five concentrations were prepared from the viral OBs mother suspension by serial dilution to be used in bioassay.

\section{Plant material}

The ripe fruits of M. azedarach were collected from El-Menoufia, Egypt, in November 2012.

\section{Preparation of crude methanol extract}

The ripe fruits of $M$. azedarach were crushed to fine particles and shade-dried at room temperature. In a $500-\mathrm{ml}$ flask, $70 \mathrm{~g}$ of crushed and dried fruits in $200 \mathrm{ml}$ of methanol were stirred for $3 \mathrm{~h}$. After leaving the methanol solution overnight, it was filtered through Whatman No. 40 filter paper. The solid filtration residue was extracted again following an identical procedure, and the two filtrates were mixed. The solvent was removed using a rotary evaporator, and a dark red residue was obtained $(14.3 \mathrm{~g} / 70 \mathrm{~g}$ plant). Series of concentrations of $M$. azedarach extract were carried out $(1.25,2.50,5.00,10.00$, and $20.00 \mathrm{~g}$ extract $/ 100 \mathrm{~g}$ diet).

\section{Bioassays \\ Insecticidal activity of virus}

Laboratory bioassay tests were conducted using diet surface treatment procedure (Addy, 1969). The SINPVs was tested against the $2^{\text {nd }}$ and $4^{\text {th }}$ instars larvae. Bioassay was performed using five concentrations of the isolated virus $\left(10^{9}, 10^{8}, 10^{7}, 10^{6}\right.$, and $\left.10^{5}\right)$. The tested larvae were starved for $4 \mathrm{~h}$ prior to feeding viruses. Bioassays were carried out in plastic cups containing semi-synthetic diet described above. $250 \mu$ l of the viral suspensions were dispersed on the diet using micropipette. Fourty larvae were used for each concentration of virus and control. Larvae of the $2^{\text {nd }}$ or $4^{\text {th }}$ instar were allowed to feed on treated diet for $48 \mathrm{~h}$, then, larvae were fed on untreated diet for 5 days. The control larvae were fed on diet treated with distilled water. All treatments were kept at $25 \pm 2{ }^{\circ} \mathrm{C}$. Mortality was recorded after 3,5 , and 7 days post infection. 


\section{Insecticidal activity of methanol extract}

Laboratory bioassay tests were conducted using diet surface treatment procedure (Addy, 1969). The methanol extract was tested against $2^{\text {nd }}$ or $4^{\text {th }}$ instars larvae. Bioassay was performed using five concentrations of the extract $(20,10,5,2.5,1.25 \mathrm{~g}$ extract $/ 100 \mathrm{~g}$ diet). Tested larvae were starved for $4 \mathrm{~h}$ prior to feeding extract. Bioassays were carried out in plastic cups containing semi-synthetic $5 \mathrm{gm}$ diet. Fourty larvae were used for each concentration of extract and control. Larvae of $2^{\text {nd }}$ or $4^{\text {th }}$ instar were allowed to feed on treated diet for $48 \mathrm{~h}$, then, larvae were fed on untreated diet for 5 days. The control larvae were fed on pure diet. All treatments were kept at $25 \pm 2{ }^{\circ} \mathrm{C}$. Mortality was recorded after 3, 5, and 7 days post treatment and larval weight was recorded on the $7^{\text {th }}$ day post treatment.

\section{Combination treatment}

$\mathrm{LC}_{50}$ values recorded after 7 days post treatment were used in combination treatment against the $2^{\text {nd }}$ and $4^{\text {th }}$ instars larvae.

\section{Statistical analysis}

The significant differences were calculated by ANOVA and Duncan's multiple range tests (ANOVA of arcsine square root transformed percentages). Differences between the treatments were determined by Tukey's multiple range test $(P<0.05)$ (Snedecor and Cochran, 1989). The $\mathrm{LC}_{50}$ values were determined by using Finney (1952) and corrected according to Abbott's formula (Abbott, 1925).

\section{RESULTS AND DISCUSSION}

As shown in Table 1 the percentages of larval weight reduction of the Melia extract against the $2^{\text {nd }}$ and $4^{\text {th }}$ instars $S$. littoralis larvae increased gradually with increasing concentrations. Generally the highest decrease in larval body weight was recorded at a concentration of $20 \mathrm{~g}$ extract $/ 100 \mathrm{~g}$ diet with the $4^{\text {th }}$ instar larvae. Larval weight reduction percentages were $35.66,38.69,40.57,42.63,47.36 \%$ and $48.12,56.93,58.42,60.23$, $64.71 \%$ for the $2^{\text {nd }}$ and $4^{\text {th }}$ instars, at $1.25,2.50,5.00,10.00,20.00 \mathrm{~g} / 100 \mathrm{~g}$ diet, respectively. 
Table 1. Effects of methanol extract of $M$. azedarach on mean larval weight and weight reduction of the $2^{\text {nd }}$ and $4^{\text {th }}$ instars larvae of $S$. littoralis.

\begin{tabular}{|c|c|c|c|c|}
\hline \multirow{3}{*}{ Treatment } & \multicolumn{4}{|c|}{ Mean larval weight (mg) and weight reduction (\%) } \\
\hline & \multicolumn{2}{|c|}{$2^{\text {nd }}$ instar } & \multicolumn{2}{|c|}{$4^{\text {th }}$ instar } \\
\hline & M. W. [mg] & W. R. (\%) & M. W. [mg] & W. R. (\%) \\
\hline Control & 11.19 & 0.00 & 69 & 0.00 \\
\hline $1.25[\mathrm{~g} / 100 \mathrm{~g}$ diet $]$ & 7.20 & $35.66^{\mathrm{e}}$ & 35.80 & $48.12^{\mathrm{e}}$ \\
\hline $2.50[\mathrm{~g} / 100 \mathrm{~g}$ diet $]$ & 6.86 & $38.69^{d}$ & 29.72 & $56.93^{d}$ \\
\hline $5.00[\mathrm{~g} / 100 \mathrm{~g}$ diet $]$ & 6.65 & $40.57^{c}$ & 28.69 & $58.42^{\mathrm{c}}$ \\
\hline $10.00[\mathrm{~g} / 100 \mathrm{~g}$ diet $]$ & 6.42 & $42.63^{b}$ & 27.44 & $60.23^{b}$ \\
\hline 20.00 [g/100g diet] & 5.89 & $47.36^{\mathrm{a}}$ & 24.35 & $64.71^{\mathrm{a}}$ \\
\hline$F$ & \multicolumn{2}{|c|}{$449.54 * * *$} & \multicolumn{2}{|c|}{$12693.23 * * *$} \\
\hline LSD & \multicolumn{2}{|c|}{0.65} & \multicolumn{2}{|c|}{0.17} \\
\hline
\end{tabular}

Values in the same column are all significantly different from each other (ANOVA, Duncan's multiple range test, $P<0.05)$.

Weight reduction\% $=[($ M.W. Control - M. W. Treatment $) /$ M. W. Control $] \times 100$.

As shown in Fig 1, M. azedarach methanol extract represents antifeeding and insecticidal activity with a remarkable retardation in larval development and significant differences in weight between the treated larvae (Fig 1- A and C) and untreated ones (Fig 1- $B$ and $D)$. 


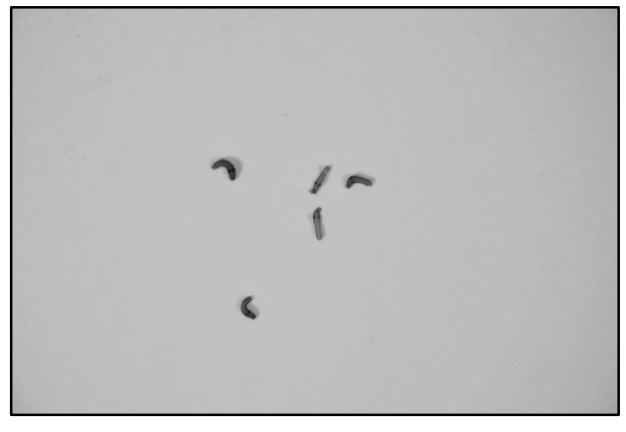

A

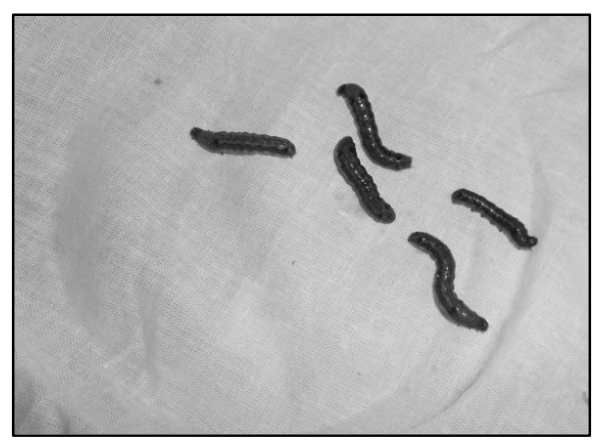

C

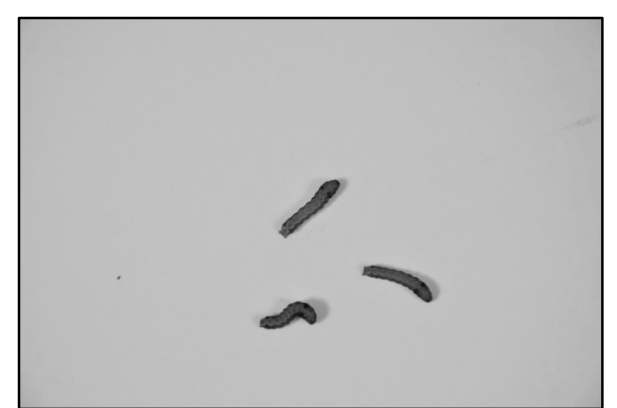

B

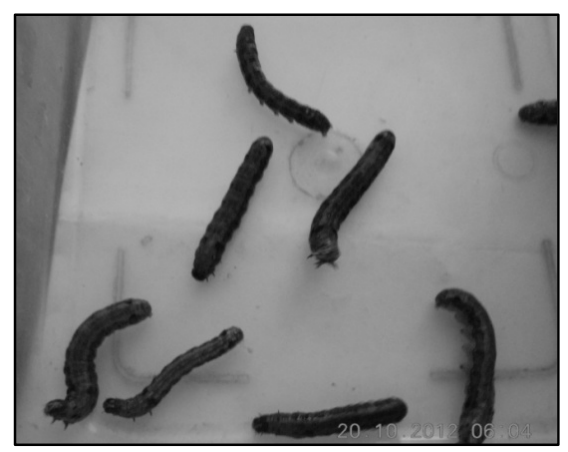

A and C: - treated $2^{\text {nd }}$ and $4^{\text {th }}$ instar larvae of $S$. littoralis $B$ and D: - untreated $2^{\text {nd }}$ and $4^{\text {th }}$ instar larvae of $S$. littoralis

Fig 1. Feeding on Melia azedarach methanol extract caused a strong inhibition of larval growth in S. littoralis (A and C) compared to control (B and D). The photos were taken after 7 days post treatment.

Larvae of Spodoptera frugiperda allowed to feed until pupation on an artificial diet to which a methanolic extract of $M$. azedarach had been added, food intake was low, growth retarded, and larval development prolonged (Breuer and Schmidt, 1990). The antifeedant and growth inhibitory activities of $M$. azedarach methanol extract to Helicoverpa armigera were investigated by Nathala and Dhingra (2005).

Data represented in Table 2 revealed that methanol extract showed significant toxic effect on $S$. littoralis larvae. The extract was slightly less effective against the $4^{\text {th }}$ instar larvae than the $2^{\text {nd }}$ instar at all concentrations. The extract recorded $47.5 \%$ 
mortality against the $4^{\text {th }}$ instar of $S$. littoralis at the highest concentration, while the extract exhibited high significant toxic effect against the $2^{\text {nd }}$ instar; the highest concentration of $20 \mathrm{~g}$ extract $/ 100 \mathrm{~g}$ diet represents $70 \%$ mortality.

The insecticidal activity of $M$. azedarach seeds was previously reported by Chiu (1987) who found that a $1 \%$ methanol extract of seed kernels of $M$. azedarach caused $80 \%$ inhibition of feeding in $1^{\text {st }}$ and $2^{\text {nd }}$ instar larvae of the noctuid Mythimna separate. Methanol extract of $M$. azedarach (12.5 and $25 \%$ ) caused $100 \%$ mortality of Aphis fabae within $96 \mathrm{~h}$ (Dimetry and Schmidt, 1991). Methanol extract of $M$. azedarach fruits had some antifeedant activity against larvae of $S$. littoralis and Agrotis ipsilon. The percentage of mortality increased with application of higher concentrations of Melia extract in both species (Schmidt et al., 1997).

Table 2. Toxic effect of methanol extract of $M$. azedarach and $\mathrm{LC}_{50}$ against $2^{\text {nd }}$ and $4^{\text {th }}$ instars larvae of $S$. littoralis after 3, 5, and 7 days post treatment.

\begin{tabular}{|c|c|c|c|c|c|c|}
\hline \multirow{2}{*}{ Treatment } & \multicolumn{2}{|c|}{ mortality $(\%)$ of the $2^{\text {nd }}$ instar } & \multicolumn{3}{c|}{ mortality (\%) of the $4^{\text {th }}$ instar } \\
\cline { 2 - 7 } & 3 days & 5 days & 7 days & 3 days & 5 days & 7 days \\
\hline Control & 0.00 & 0.00 & 0.00 & 0.00 & 0.00 & 0.00 \\
\hline $1.25[\mathrm{~g} / 100 \mathrm{~g}$ diet] & $7.50^{\mathrm{e}}$ & $12.50^{\mathrm{d}}$ & $17.50^{\mathrm{e}}$ & $0.00^{\mathrm{d}}$ & $0.00^{\mathrm{e}}$ & $10.00^{\mathrm{e}}$ \\
\hline $2.50[\mathrm{~g} / 100 \mathrm{~g}$ diet] & $22.50^{\mathrm{d}}$ & $32.50^{\mathrm{c}}$ & $40.00^{\mathrm{d}}$ & $0.00^{\mathrm{d}}$ & $7.5^{\mathrm{d}}$ & $15.00^{\mathrm{d}}$ \\
\hline $5.00[\mathrm{~g} / 100 \mathrm{~g}$ diet $]$ & $25.00^{\mathrm{c}}$ & $37.50^{\mathrm{b}}$ & $45.00^{\mathrm{c}}$ & $10^{\mathrm{c}}$ & $17.5^{\mathrm{c}}$ & $30.00^{\mathrm{c}}$ \\
\hline $10.00[\mathrm{~g} / 100 \mathrm{~g}$ diet $]$ & $30.00^{\mathrm{b}}$ & $37.50^{\mathrm{b}}$ & $62.50^{\mathrm{b}}$ & $15^{\mathrm{b}}$ & $25^{\mathrm{b}}$ & $37.50^{\mathrm{b}}$ \\
\hline $20.00[\mathrm{~g} / 100 \mathrm{~g}$ diet] & $35.00^{\mathrm{a}}$ & $42.50^{\mathrm{a}}$ & $70.00^{\mathrm{a}}$ & $25^{\mathrm{a}}$ & $32.5^{\mathrm{a}}$ & $47.50^{\mathrm{a}}$ \\
\hline LC 50 & 56.22 & 28.44 & 5.94 & 45.4 & 36.18 & 20.82 \\
\hline$F$ & 240.27 & 315.37 & 5037.20 & 6750 & 20475 & 2647.50 \\
\hline LSD & 2.11 & 2.08 & 0.91 & 0.41 & 0.90 & 0.91 \\
\hline
\end{tabular}

Values in the same column are all significantly different from each other (ANOVA, Duncan's multiple range test, $P<0.05)$.

Data presented in Table 3 revealed that the mortality percentages of the two tested instars larvae treated with SINPVS were increased with increasing the concentrations and time elapsed post treatment. The highest concentration of the NPVs $\left(10^{9} \mathrm{OBs} / \mathrm{ml}\right)$ showed 85 and $75 \%$ mortality against the $2^{\text {nd }}$ and $4^{\text {th }}$ instars, respectively after 7 days. The $4^{\text {th }}$ instar larvae showed to be less susceptible to the virus than the $2^{\text {nd }}$ instar. 
Table 3. Toxic effect of virus and $\mathrm{LC}_{50}$ against the $2^{\text {nd }}$ and $4^{\text {th }}$ instars larvae of $S$. littoralis after 3,5, and 7 days post treatment.

\begin{tabular}{|c|c|c|c|c|c|c|}
\hline \multirow{2}{*}{ Treatment } & \multicolumn{3}{|c|}{ mortality (\%) of the $2^{\text {nd }}$ instar } & \multicolumn{3}{c|}{ mortality (\%) of the $4^{\text {th }}$ instar } \\
\cline { 2 - 7 } & 3 days & 5 days & 7 days & 3 days & 5 days & 7 days \\
\hline Control & 0.00 & 0.00 & 0.00 & 0.00 & 0.00 & 0.00 \\
\hline $10^{5}[\mathrm{OBs} / \mathrm{ml}]$ & $37.5^{\mathrm{c}}$ & $50^{\mathrm{e}}$ & $65^{\mathrm{d}}$ & $32.5^{\mathrm{b}}$ & $47.5^{\mathrm{d}}$ & $50^{\mathrm{e}}$ \\
\hline $10^{6}[\mathrm{OBs} / \mathrm{ml}]$ & $42.5^{\mathrm{b}}$ & $57.5^{\mathrm{d}}$ & $75^{\mathrm{c}}$ & $32.5^{\mathrm{b}}$ & $47.5^{\mathrm{d}}$ & $57.5^{\mathrm{d}}$ \\
\hline $10^{7}[\mathrm{OBs} / \mathrm{ml}]$ & $45^{\mathrm{b}}$ & $62.5^{\mathrm{c}}$ & $75^{\mathrm{c}}$ & $35^{\mathrm{b}}$ & $50^{\mathrm{c}}$ & $62.5^{\mathrm{c}}$ \\
\hline $10^{8}[\mathrm{OBs} / \mathrm{ml}]$ & $45^{\mathrm{b}}$ & $67.5^{\mathrm{b}}$ & $80^{\mathrm{b}}$ & $35^{\mathrm{b}}$ & $55^{\mathrm{b}}$ & $65^{\mathrm{b}}$ \\
\hline $10^{9}[\mathrm{OBs} / \mathrm{ml}]$ & $50^{\mathrm{a}}$ & $70^{\mathrm{a}}$ & $85^{\mathrm{a}}$ & $40^{\mathrm{a}}$ & $60^{\mathrm{a}}$ & $75^{\mathrm{a}}$ \\
\hline $\mathrm{LC}$ 50 & $1.47 \times 10^{9}$ & $5.57 \times 10^{4}$ & 124.96 & $1.5 \times 10^{15}$ & $2.41 \times 10^{6}$ & $9.15 \times 10^{4}$ \\
\hline$F$ & 16.5 & 154.5 & 26.40 & 11.25 & 70.5 & 205.5 \\
\hline $\mathrm{LSD}$ & 3.52 & 2.03 & 4.55 & 2.88 & 2.03 & 2.03 \\
\hline
\end{tabular}

Values in the same column with the same letter are not significantly different from each other (ANOVA, Duncan's multiple range tests, $P<0.05)$.

The symptoms of viral infection can be classified into three stages:-

Initial stage of infection Fig (2-A):- In the initial stage of infection there was changing in the activity of infected larvae comparing to healthy one in which infected larvae show reduced motor function, their feeding begins to slow and virtually ceases, milky color seen on the cuticle which appear pale and thin.

Intermediate stage of infection Fig (2-B):- In this stage the invasion of viral occlusion bodies spread the infection throughout the whole host and damage all host cells and the larval body begins to appear swollen due to the complete destruction of all internal tissues organs.

Final stage of infection Fig (2-C):- in the final stage the host becomes packed with viral occlusion bodies and fragile epidermis ruptures releasing millions of viral occlusion bodies back into the environment to spread the infection to another host. 

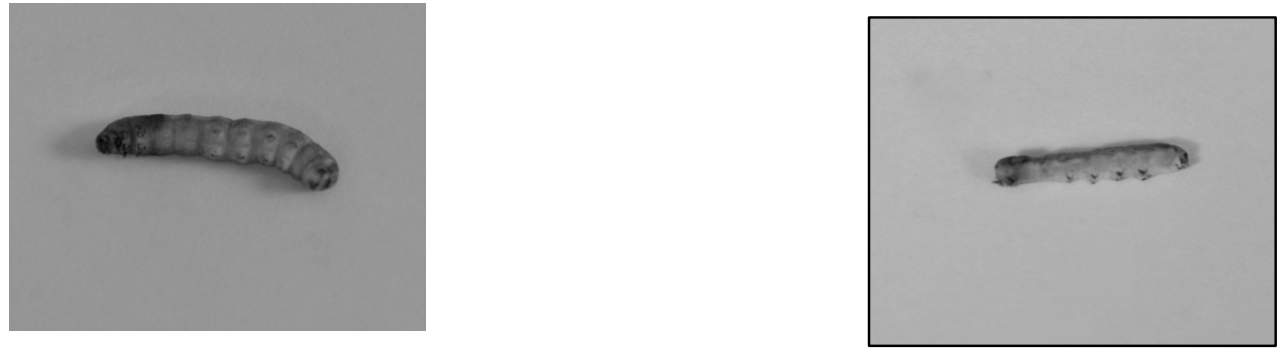

Fig (2-A)

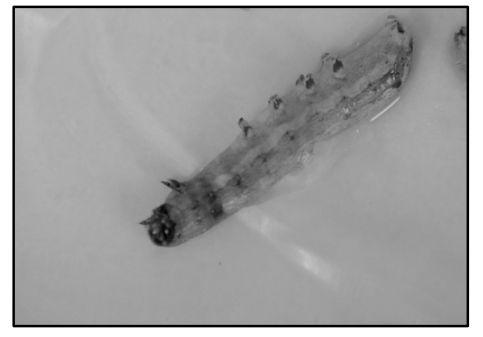

Fig (2-B)
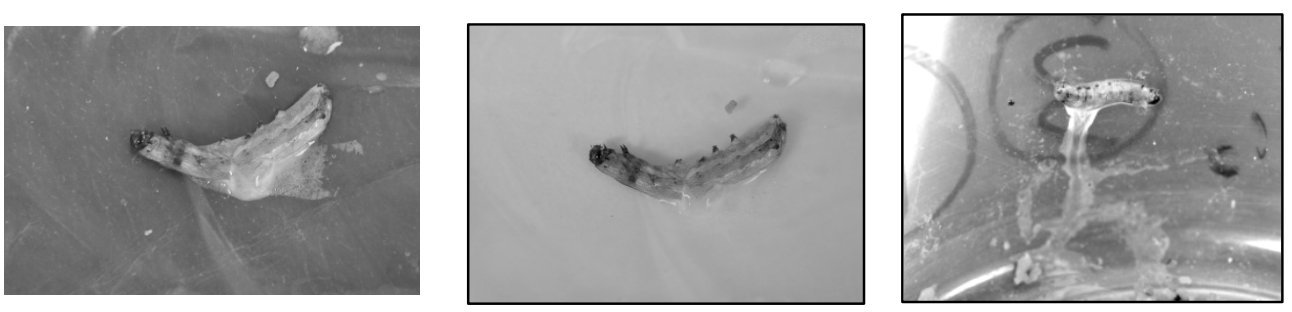

Fig (2-C)

Fig (2-A):- Slow motion larvae and cuticle showing milky color Fig (2-B):- Swollen of larval body due to invasion of viral occlusion bodies Fig (2-C):- liquefied larval body

The results of the present study showed that, high concentrations of NPVs caused a high mortality rate; this conclusion is parallel to that found by Duan and Otvos (2001) who reported that mortality was higher when younger larvae of Choristonura fumiferana were used. 
In this study bioassays carried out with the two larval instar tested revealed that the $S$. littoralis larvae showed symptoms during the first three days post-inoculation, these observations agree with Federici (1997) who confirmed that in typical NPV infections, such as the disease caused by the NPV of Autographa californica (Speyer.) (Lepidoptera: Noctuidae) (AcMNPV), Trichoplusia ni (Hubnar.) (Lepidoptera: Noctuidae) (TnMNPV) and Helicoverpa zea (Boddie.) (Lepidoptera: Noctuidae) (HzMNPV) there are few signs of disease during the first 3 days of infection.

On or near the $4^{\text {th }}$ day, infected larvae begin to respond much more slowly than healthy larvae to stimuli such as touching Federici (1997). In our study, it was also noted that when healthy larvae were dropped from a low height, they collected themselves on their legs, but the infected larvae gave no such response and instead lay on their dorsal side. This situation can be related to the infection of the central nervous system and muscle cells. Thus, when a larva started to lose control of the central nervous system, it was not possible to respond to surroundings. By the $4^{\text {th }}$ day of post-inoculation, infected larval cuticle showed pale and milky color and thinning. This symptom can be associated with the beginning of infection of hypodermal cells. The most typical symptoms are noted in larval stages where either whitening or yellowing of the gut and /or the remainder of the body organs is associated with infection and replication by Evans and Shapiro (1997).

Our results showed that the larvae became less active and generally lost its appetite, though some were known to continue to feed up to a few days before death. Thinner appearance of the cuticle can be associated with the activities of cathepsin and chitinase genes in the baculoviruse genome. All these observation are in accordance to results reported by Tanada and Kaya (1993).

Following the $4^{\text {th }}$ day, infected larvae showed swollen bodies. This could be due to the infection of nuclei and the hypertrophy that had occurred in the cell. Tanada and Kaya (1993) approved that the nucleus increased in size due to the baculovirus infection. In NPV infection, at day 4 or 5 , the larvae will begin to appear swollen and the cuticle can appear flaccid (Federici, 1997). In the final stage of infection, OBs are formed and the nuclei are packed with OBs which causes the cellular hypertrophy and swollen appearance of the infected larvae Oecd (2002). Thus, the hypertrophy in the nucleus is an important sign of NPV infection and causes insect swollen.

In the baculovirus biological cycle, release of the polyhedra to the environment is the most important step. Release of the polyhedra to environment is only possible with the liquefaction of the host. The swollen of the cuticle is the beginning of the process that will bring the host to liquefaction. Both swollen of the cuticle and liquefaction are associated with the activities of cathepsin, proteinase and chitinase 
genes of baculoviruses. These baculovirus genes have the principle role of damaging whole larval body.

The combination between the NPVs and the extract increase the effectiveness of both of them against $S$. littoralis. As shown in Table 4 the combination between the virus and the extract at the $\mathrm{LC}_{50}$ concentrations gave $95 \%$ and $87.5 \%$ mortality for the $2^{\text {nd }}$ and $4^{\text {th }}$ instar, respectively after 7 days.

Table 4. The effects of combination between the virus and extract at the $\mathrm{LC}_{50}$ concentrations against the $2^{\text {nd }}$ and $4^{\text {th }}$ instars larvae.

\begin{tabular}{|c|c|c|c|c|c|c|}
\hline \multirow{2}{*}{$\begin{array}{c}\text { Combination } \\
\text { treatment }\end{array}$} & \multicolumn{3}{|c|}{$2^{\text {nd }}$ instar } & \multicolumn{3}{c|}{$4^{\text {th }}$ instar } \\
\cline { 2 - 7 } & 3 days & 5 days & 7 days & 3 days & 5 days & 7 days \\
\hline Mortality\% & 65 & 80 & 95 & 50 & 70 & 87.5 \\
\hline Reduction in wt \% & - & - & 95 & - & - & 52.05 \\
\hline
\end{tabular}

The results of the present study showed that NPVs and methanol extract of $M$. azedarach combination can provide control of $S$. littoralis larval populations, which is comparable with, superior to, that provided by a botanical insecticide or virus alone. In addition, there were greater mean larval weight loses in larvae fed on combined treatment of extract and NPV as compared to control larvae. The present finding also showed reduced development rate in treated larvae and this similar to Nathan and Kalaivani, (2005) using azadirachtin (AZA) and Spodoptera nucleopolyhedrovirus (SpltNPV). It may be concluded from this study that extended larval period is coupled with lower developmental rate with increased mortality. A similar result was reported by Shapiro et al., (1994) using aqueous neem extract in combination with (Lymantria dispar L.) gypsy moth NPV.

\section{CONCLUSION}

Melia extract and SINPV combination can provide control of S. littoralis larval populations, which is comparable with, superior to, that provided by a botanical insecticide or virus alone. The greatest advantage of SINPV and methanol extract of M. azedarach combination is the potential decrease in the pathogen dosage required to kill larvae, the faster kill and negative effects on growth and development which could result lesser feeding damage to the host plant. 


\section{REFERENCES}

1. Abbott W. S. A. 1925. Method for computing the effectiveness of an insecticide. J. Econ. Entomol. 18: 265.

2. Abou-Fakhr Hammad, E. M., M. M. M. Hammad , M. T. Farran. 2013. Effect of Melia azedarach (Sapindales: Meliaceae) fruit extracts on Citrus Leafminer Phyllocnistis citrella (Lepidoptera: Gracillariidae). SpringerPlus, 2:144.

3. Addy, N. D. 1969. Rearing the forest tent caterpillar on an artificial diet. J. Econ. Entomol. 62: 270-271.

4. Breuer, M. and G. H. Schmidt. 1990. Studies on the effect of Melia azedarach extracts on Spodoptera frugiperda (J.E. Smith) (Lepidoptera: Noctuidae); Mitteilungen der Deutschen Gesellschaft fur Allgemeine und Angewandte Entomologie, 7(4-6): 419-429.

5. Chiu, S. F. Experiments on the practical application of chinaberry, Melia azedarach, and other naturally occurring insecticides in China; Proceedings of the $3^{\text {rd }}$ International Neem Conference, Nairobi, Kenya, 10 -15 July - 1986. Deutsche Gesellschaft fur Technische Zusammenarbeit, Eschborn, 1987, pp. 661-668.

6. Duan, L. and I. S. Otvos. 2001. Influence of larval age and virus concentration on mortality and sublethal effects of a nucleopolyhedrovirus on the Western Spruce Bud worm (Lepidoptera:Tortricidae). J. Environ. Entomol., 30: 136-146.

7. Dimetry, N. Z. and G. H. Schmidt. 1991. Improvements of methanol extracts of Melia azedarach by some additives against Aphis fabae Scop; Bollettino di Zoologia Agraria e di Bachicoltura, 23(2): 143-151.

8. El-Defrawi, M. E., A. Toppozada, N. Mansour and M. Zeid. 1964. Toxicological studies on Egyptian cotton leaf worm Prodenia litura (F.). I: Susceptibility of different larval instars to insecticides. J. Econ. Entomol. 57: 591 - 593.

9. Ellis, S. E. 2004. New Pest Response Guidelines: Spodoptera. USDA/APHIS/PPQ/PDMP.

10. Evans, H. and M. Shapiro. 1997. Manual of Techniques in Insect Pathology. Academic Press Ltd., London.Viruse. pp. 17-53.

11. Farag, M., M. H. M. Ahmed, H. Yousef, and A. A.-H. Abdel-Rahman. 2011. Repellent and insecticidal activities of Melia azedarach L. against cotton leafworm Spodoptera littoralis (Boisd.). Z. Naturforsch. 66c: 129-135.

12. Federici, B. A. 1997. Baculovirus pathogenesis. In: Miller, L.K. (Ed.), The Baculoviruses. Plenum Press, New York. pp. 33-59. 
13. Finney, D. J. 1952. Probit Analysis, Cambridge University Press, Cambridge. 333pp.

14. Moscardi, F. Assessment of the application of baculoviruses for control of Lepidoptera. Annu. Rev. Entomol., 44 (1999), pp. 257-289.

15. Nathala, E. and S. Dhingra. 2005. Relative effect of various extracts of Melia azedarach (Linn) leaf against Helicoverpa armigera (Hubner) and their comparison with seed extracts. Journal of Entomological Research, 29(3): 201206.

16. Nathan, S. S. and K. Kalaivani. 2005. The effects of azadirachtin and nucleopolyhedrovirus on midgut enzymatic profile of Spodoptera litura Fab. (Lepidoptera: Noctuidae). Pest. Biochem. Physiol., 83: 46-57.

17. Oecd. 2002. Consensus document on information used in the assessment of environmental applications involving baculoviruses. Series on Harmonization of regulatory Oversight in Biotechnology, No:20.

18. Schmidt, G. H., A. A. I. Ahmed and M. Breuer. 1997. Effect of Melia azedarach extract on larval development and reproduction parameters of Spodoptera littoralis (Boisd.) and Agrotis ipsilon (Hufn.) (Lep. Noctuidae). Anzeiger fur Schadlings kunde, Pflanzenschutz, Umweltschutz, 70(1): 4-12.

19. Snedecor, G. W. and W. G. Cochran. 1989. Statistical Methods, 8th ed. Iowa State University Press, Ames, IA, USA.

20. Shapiro, M., J. L. Robertson and R. E. Webb. 1994. Effect of neem seed extract upon the gypsy moth (Lepidoptera: Lymantriidae) and its nuclear polyhedrosis virus. J. Econ. Entomol., 87: 356-360.

21. Sharma, M. K , I. D. Sharma, K. C. Sharma. 2012. Effect of Melia extracts on oviposition, gonad development and field infestation of melon fruit fly (Bactrocera tau) in cucumber (Cucumis sativus). Indian Journal of Agricultural Sciences, 82(6): 523-527.

22. Sudhakar, S., R. Varatharajan, and S. Mathavan. 1997. Simple method to purify polyhedral inclusion bodies from Nosema (Microspora: Nosmatidae) contamination; Entomo 22: 89-93.

23. Tanada, Y. and H. Kaya. 1993. Systemic infection of nuclear polyhedrosis virus. Insect pathology, Academic Press Inc.ISBN 0-12-683255-2, San Diego, California. 


\section{تأثير الخلط بين مستخلص الميثانول للزنزلخت والفيروس النووي لاودة ورق القطن علي دودة ورق القطن}

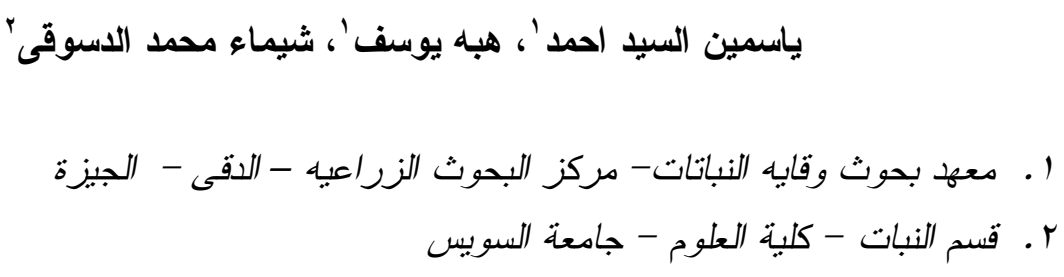

أجريت الدراسة فى هذا البحث بغرض اختبار سمية مستخلص الميثانول لنبات الزنزلخت

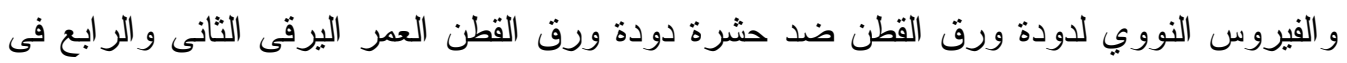

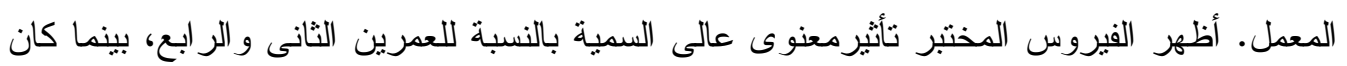

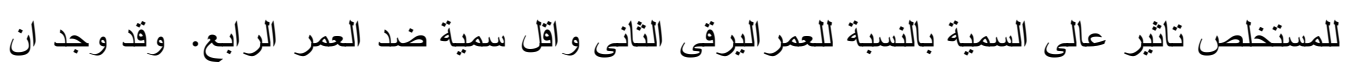

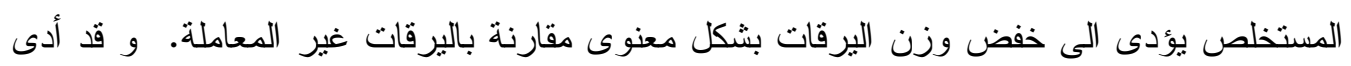

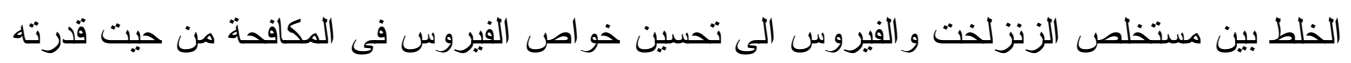
على قتل اليرقة اسرع و ايضا تقليل وزن و نمو اليرقات مما يقلل من التلف الممكن حدوثة نتيجة 